\title{
DUKUNGAN KLINIK IPTEK MINA BISNIS (KIMBis) PADA PROGRAM PEMBERDAYAAN USAHA GARAM RAKYAT (PUGAR) DI KABUPATEN PATI
}

\section{Acceptance of Iptek Mina Business (KIMBis) Clinic in The Folk Salt Business Development Program (Pugar) In Pati Regency}

\author{
*Sapto Adi Pranowo dan Muhajir \\ Balai Besar Penelitian Sosial Ekonomi Kelautan dan Perikanan \\ Gedung Balitbang KP I Lt. 4 \\ Jalan Pasir Putih Nomor 1 Ancol Timur, Jakarta Utara \\ Telp: (021) 64711583 Fax: 64700924r 2015 \\ *e-mail: saptoadipran@gmail.com
}

Diterima 5 September 2014 - Disetujui 25 Mei 2015

\begin{abstract}
ABSTRAK
Penilitian ini bertujuan untuk mendukung Program PUGAR di Pati dalam meningkatkan produktifitas, kualitas dan harga garam krosok di tingkat petambak garam. Penelitian dilakukan di Kecamatan Batangan, Kabupaten Pati, dari pertengahan tahun 2013 sampai dengan bulan Agustus 2015. Responden ditentukan secara sengaja (purposive), yaitu petambak garam yang mendapat pengawalan dan bimbingan langsung dari Klinik Iptek Mlna Bisnis (KIMBis) dalam menerapkan teknologi tepat guna pembuatan garam. Data primer diperoleh dari hasil pelaksanaankaji terap teknologi pembuatan garam, sedangkan data sekunder diperoleh melalui studi pustaka. Pengolahan data dilakukan dengan analisis biaya manfaat dan diuraikan secara diskriptif. Hasil penelitian menunjukkan bahwa penerapan Teknologi Tepat Guna (TTG) Sistem Teknologi Ulir Filter (TUF) dengan Media Isolator dapat meningkatkan produktifitas garam 169\%, kualitas garam KW 1 dan harga garam Rp 500 per $\mathrm{kg}$ di tingkat petambak. Implikasi kebijakan dari hasil penelitian ini adalah pemerintah pusat yang terkait dengan komoditas garam Kementrian Kelautan dan Perikanan (KKP), Perindustrian, Perdagangan dan Koperasi) diharapkan dapat menjaga stabilitas harga garam yang telah ditentukan dengan cara membuat kebijakan tentang pemasaran garam mulai dari daerah produsen hingga pabrik pengolahan /industri yang membutuhkan garam dan memperdayakan koperasi garam dalam penerapan teknologi dan pemasaran garam, sedangkan pemerintah daerah memberikan dukungan sepenuhnya dengan mengeluarkan regulasi pegaraman.
\end{abstract}

Kata Kunci: dukungan; Kimbis; pugar; Pati

\section{ABSTRACT}

This study aims to support the Program PUGAR in Pati in improving the productivity, quality and price level of salt at the salt farmers. The study was conducted in the Batang District, Pati Regency, from mid-2013 until August 2015. Respondents were determined intentionally (purposive), the salt farmers are under guard and direct guidance of KIMBis in applying appropriate technologies salt production. Primary data obtained from the review of the implementation of the therapy, salt-making technology, while secondary data obtained through library. Data processing is done by a cost benefit analysis and described descriptively. The results showed that the application of TTG Systems TUF Media with Isolator can increase the productivity of $169 \%$ salt, $1 \mathrm{KW}$ salt quality and price of Rp 500 per $\mathrm{kg}$ of salt at the farmer level. The policy implication of this study is that the central government related to commodities salt (CTF, Industry, Trade and Cooperatives) is expected to maintain the stability of the price of salt that has been determined by making policy on the marketing of salt ranging from the producer to processing factories / industries requiring salt and salt cooperative overreach in the application of technology and marketing of salt. While the local government provides full support by issuing regulations saltworks.

Keywords: acceptancet; Kimbis; PUGAR; Pati 


\section{PENDAHULUAN}

Permasalahan utama pada pegaraman adalah rendahnya produktifitas,kualitas dan harga garam krosok. Untuk meningkatkan pendapatan petambak garam, pada tahun 2011, pemerintah melalui Kementerian Perdagangan telah mengeluarkan peraturan tentang penetapan harga garam di tingkat petambak berdasarkan kualitas garam dengan ketentuan Garam Kualitas 1 (KW 1) dengan kandungan $\mathrm{NaCl} \geq 94,7 \%$ ditetapkan Rp 750/kg, sedangkan Garam KW 2 dengan kandungan $\mathrm{NaCl}: 85,0$ 94,6\% ditetapkan Rp 550/kg (Ditjen Perdagangan LN, 2011). Kondisi di lapang sampai dengan tahun 2012 menunjukkan bahwa harga garam per kg di tingkat petambak masih di bawah Rp 550 , karena kadar $\mathrm{NaCl}$ garam krosok yang dihasilkan petambak Pati, berkisar $75 \%$ - $85 \%$ (Hariyanto, 2013). Penyebab dari permasalahan garam di Pati dapat dikelompokkan menjadi tiga aspek yaitu dari aspek teknis, ekonomi dan aspek soaial.Secara teknis dalam pembuatan garam masih menggunakan cara tradisional (belum ada sentuhan teknologi pembuatan garam). Secara ekonomi, keterbatasan modal usaha dari pembuat garam dan secara sosial adalah latar belakang pendidikan dan status sosial pembuat garam. yang pada umumnya hanya lulusan sekolah dasar sehingga sulit untuk menerima perubahan terutama yang terkait dengan teknologi dan permodalan.

Hasil penelitian (Erlina, et al., 2013), memberikan informasi bahwa. Permasalahan utama yang dihadapi dalam pembuatan garam adalah ketersediaan modal awal dalam pembuatan garam, karena semua kebutuhan modal dalam pembuatan garam ditanggung oleh pembuat garam atau "pemadak". Latar belakang pemadak pada umumnya adalah golongan masyarakat kelas bawah yang kondisi perekonomiannya terbatas, sehingga untuk memenuhi permodalan tersebut dilakukan dengan cara meminjam kepada pemilik modal (pemilik lahan, pedagang pengumpul atau tengkulak) dengan jaminan penjualan garam hasil panen kepada pemberi pinjaman.Sehingga pemadak tidak mempunyai nilai tawar dalam menjual garam yang dihasilkan. Selain itu, latar belakang pendidikan pemadak paling tinggi hanya lulusan SD dan dalam pembuatan garam mereka mencontoh para leluhurnya dengan cara tradisional, sehingga mereka sulit untuk menerima inovasi baru dalam pembuatan garam.
Salah satu penyebab rendahnya kualitas garam adalah tidak adanya sentuhan teknologi dalam pembuatannya, sehingga pemerintah (KKP) melalui Program PUGAR Tahun 2013 dan Tahun 2014 telah menargetkan bahwa peningkatan produktivitas dan kualitas garam harus dilakukan dengan sentuhan Teknologi Tepat Guna (TTG) dalam pembuatan garam dengan menerapkan Sistem Teknologi Ulir Filter (TUF) dengan menggunakan media isolator (Ditjen KP3K, 2014). Namun demikian pelaksanaan program PUGAR di Pati Tahun 2013 tidak dapat berjalan dengan baik, karena adanya penolakan penggunaan isolator dalam pembuatan garamoleh petambak garam. Hal ini dikarenakan tidak adanya sosialisasi dan bintek tentang penggunaan isolator kepada pegaram, adanya perbedaan ukuran isolator dengan mejaan garam yang telah dibuat,selain itu kedatangan bantuan media isolator terlambat yaitu pada akhir musim garam (bulan September 2014) dan tidak adanya jaminan harga terhadap garam hasil produksi TTG.

Terkait dengan permasalahan tersebut, maka diperlukan adanya kelembagaan yang berfungsi untuk pemberdayaan masyarakat secara aktif dan bersifat multi fungsi yang berperan sebagai lembaga konsultasi dan mediasi dalam memecahkan permasalahan. Klinik Iptek Mina Bisnis (KIMBis) merupakan lembaga masyarakat kelautan dan perikanan, yang dibentuk secara partisipatif oleh berbagai pemangku kepentingan untuk merebut berbagai peluang dalam rangka mewujudkan kesejahteraan masyarakat (BALITBANGKP, 2012). Salah satu fungsi dan peran KIMBis adalah menyebarkan teknologi tepat guna kepada masyarakat (Zulham, 2012). Oleh sebab itu KIMBis ikut bertanggung jawab terhadap penyebaran teknologi tepat guna pembuatan garam dengan sistem Teknologi Ulir Filter degan menggunakan media isolator. Tulsan ini menjelaskan bagaimanapenerapan fungsi dan peran KIMBis dalam memasyarakatkan teknologi tepat guna pada pembuatan garam untuk meningkatkan harga garam.

\section{METODOLOGI}

Penelitian ini dilaksanakan di Kecamatan Batangan, Kabupaten Pati salah satu sentra pembuatan garam. Responden ditentukan secara sengaja (purposive) yaitu petambak garam yang mendapat pengawalan dan bimbingan 
langsung dari KIMBis dalam menerapkan teknologi tepat guna pembuatan garam metode ini di lakukan survei dengan lingkungan. Waktu penelitian dilakukan mulai dari pertengahan tahun 2013. Data primer diperoleh dari hasil pelaksanaan kaji terap teknologi pembuatan garam, sedangkan data sekunder diperoleh melalui studi pustaka. Pengolahan data dilakukan dengan analisis biaya manfaat $(R / C$ Ratio) dan diuraikan secara diskriptif (Sutoyo, 2001 \& Agung, 2011)

\section{HASIL DAN PEMBAHASAN}

\section{Keragaan Pegaraman di Kabupaten Pati}

Kabupaten Pati mempunyai lahan tambak potensi untuk pembuatan garam seluas $3.307 \mathrm{Ha}$ dan lahan tambak garam yang sudah berproduksi seluas $2.563 \mathrm{Ha}$. Daerahlokasilahantambak tersebar di empat kecamatan yaitu Kecamatan Batangan (tujuh desa), Kecamatan Juwana (empat desa), Kecamatan Wedarijaksa (tiga desa), dan kecamatan Trangkil (empat desa) (Dinas KP Pati, 2011).Kondisi lahan pertambakan garam untuk wilayah Kacamatan Batangan sampai Kecamatan Yuwana sangat potensial untuk pembuatan garam, sehingga garam merupakan andalan utama dari usaha tambak dari pada kegiatan perikanan. Mata pencaharian masyarakat Kecamatan Batangan sebagian besar berusaha di pegaraman sebagai pembuat garam, pengolah garam dan pedagang garam. Kondisi tersebut ditunjukkan dengan jumlah pengolah garam di Kecamatan Batangan sebanyak 59 unit dari total pengolah garam di wilayah Kabupaten Pati sebanyak 60 unit (Dinas KP, 2012). Sementara untuk lahan tambak garam yang terletak di wilayah Kecamatan Wedarijaksa dan Kecamatan Trangkil merupakan lahan tambak multi fungsi artinya pada saat musim kemarau lahan tambak dimanfaatkan untuk pembuatan garam sedangkan pada musim penghujan dimanfaatkan untuk budidaya perikanan (bandeng, nila, udang). Pemilik tambak lebih mengutamakan budidaya perikanan dari pada pembuatan garam, sehingga pada saat musim kemarau/garam pemilik tambak tidak mau mengelola tambaknya untuk pembuatan garam. Pembuatan garam dilakukan oleh buruh pembuat garam (pemadak) yang sudah menjadi patner usaha dari leluhurnya, artinya hubungan pemadak dengan pemilik merupakan warisan turun temurun selama hubungan tersebut tidak ada masalah. Pemadak bertanggung jawab penuh terhadap usaha pegaraman yang dilakukan mulai dari awal proses persiapan penataan lahan, proses pembuatan garam, panen dan pemasarannya. Semua biaya operasional yang terkait dengan pembuatan garam hingga panen dan penjualannya ditanggung oleh pemadak, sehingga kondisi perekonomian pemadak memberikan pengaruh besar terhadap kualitas dan harga garam.Kondisi perekonomian pembuat garam/pemadak pada umumnya golongan ekonomi lemah yang selalu dituntut untuk pemenuhan hajat hidup, maka dalam membuat garam hanya brorientasi cepat panen dan cepat mendapatkan uang sehingga mereka dapat membuat garam lagi, tanpa memikirkan dan memperhatikan kondisi garam yang dipanen. Kondisi inilah yang membuat harga garam rendah (40\% dari harga standart) dan merusak citra garam Pati.

Mekanisme rantai pemasaran garam di Kabupaten Pati pada umumnya dilakukan secara langsung, yaitu produsen garam menjual ke pedagang pengumpul melalui tengkulak/broker yang berkeliaran di lingkungan tambak. Dari pedagang pengumpul dijual ke pedagang besar kemudian dijual ke pengolah garam beryodium. Setelah garam diolah menjadi garam konsumsi beryodium dijual ke luar daerah melalui agen di masing-masing lokasi pemasaran. Tengkulak/ broker, Pedagang pengumpul biasanya berdomisili di satu kecamatan dengan produsen (lokasi tambak), sedangkan pedagang besar berada diluar kecamatan lokasi tambak atau satu lokasi dengan produsen pengolahan garam. Untuk mendapatkan harga garam yang lebih murah dari pasaran, biasanya para tengkulak/ pedagang garam memberikan pinjaman dana sebagai ikatan kepada para pemadak untuk kebutuhan hidup atau operasional dalam pembuatan garam. Dengan adanya ikatan tersebut pemadak tidak dapat memilih pasar dan tidak mempunyai posisi tawar, sehingga harus patuh kepada pedagang yang memberikan pinjaman. Kondisi tersebut merupakan salah satu faktor penghambat dalam memajukan usahapegaraman di wilayah Kabupaten Pati.

\section{Peran KIMBis dalam Pelaksanaan Program PUGAR}

Keseriusan KKP dalam mengelola garam, diwujudkan dengan pencanangan Gerakan 
Swasembada Garam Nasional pada tahun 2010 dengan sasaran; Pemenuhan garam konsumsi pada tahun 2012, Pemenuhan kebutuhan garam industri pada tahun 2015, dan Peningkatan daya saing produksi garam rakyat untuk melepas ketergantungan terhadap garam impor serta terwujudnya kelembagaan yang mampu memperjuangkan kepentingan masyarakat petambak garam. Untuk mewujudkan tujuan tersebut, pada tahun 2011 telah dibuat Program Pemberdayaan Usaha Garam Rakyat (PUGAR). Pemberdayaan masyarakat dalam hal ini diartikan sebagai upaya menumbuhkan kapasitas dan kemampuan masyarakat untuk meningkatkan posisi tawar (bargaining position) sehingga memiliki akses dan kemampuan untuk mengambil keuntungan timbal balik dalam bidang sosial dan ekonomi (Ditjen KP3K, 2012).

Pelaksanaan Program PUGAR pada tahun 2011 lebih dititik beratkan pada perbaikan infra struktur yang terkait dengan kegiatan pembuatan garam (saluran air) dalam rangka meningkatkan produksi guna pemenuhan kebutuhan garam konsumsi. Hasil pelaksanaan Program PUGAR di Pati Tahun 2011adalah peningkatan produksi garam dan Pati telah berhasil memberikan kontribusi produksi garam sebesar $15,5 \%$ (251.880 ton) dari total produksi garam nasional 1.623.786 ton dan menempati urutan ke-dua setelah Kabupaten Sumenep (Direktur PMPPU. 2012). Namun keberhasilan peningkatan produksi garam krosok masih belum dapat dinikmati oleh pembuat garam karena kualitas garamnya paling tinggi masuk dalam KW 3 yang dihargai Rp 250 - Rp 350 per kg di tambak. Terkait dengan permasalahan tersebut, Program PUGAR pada tahun 2013 lebih ditekankan pada peningkatan produktivitas dan kualitas garam rakyat melalui pemberdayaan masyarakat. Dalam rangka mendukung pelaksanaan program tersebut, KIMBis "BUMI SARMINA PATI" yang baru dibentuk dan mempunyai peran sebagai fasilitator pengembangan bisnis, telah berusaha mencarikan teknologi tepat guna dalam pembuatan garam. KIMBis Pati telah berhasil memfasilitasi sebagian masyarakat petambak garam Pati untuk melakukan studi banding ke penemu Teknologi Ulir Filter (TUF) di LosariCirebon, dan melakukan uji coba pembuatan garam dengan sistem TUF yang dibimbing dan dikawal langsung oleh penemunya (P Sanusi). Garam yang dihasilkan secara visual ditunjukkan dengan warna putih bersih cenderung bening, butiran garam berupa kristal dengan ukuran $\leq$ $0,4 \mathrm{~mm}$ dan ada indikasi peningkatan produksi sekitar $20 \%$ dari produksi garam tradisional. Pelaksanaan kegiatan PUGAR di Pati tahun 2013 masih belum dapat mencapai tujuan/ sasaran yang ditargetkan yaitu peningkatan produktivitas dan kualitas garam rakyat, sehingga tujuan dan sasaran tersebut masih tetap akan dilanjutkan pada Program PUGAR Tahun 2014 dengan mengimplementasikan Teknologi Ulir Filter (TUF), dan/atau teknologi geomembran/ isolator (Dirjen KP3K, 2014).

Target kualitas garam yang ingin dicapai pada tahun 2014 adalah garam rakyat masuk dalam KW 1 yang memenuhi syarat untuk bahan industri maupun untuk konsumsi. Secara visual garam KW 1 ditunjukkan dengan warna putih bersih cenderung bening, butiran garam berupa kristal dengan ukuran minimal 0,5 mm. Dan secara kimiawi mempunyai komposisi sebagai berikut : $\mathrm{NaCl}: 97.46 \% ; \mathrm{CaCl} 2: 0.723 \%$; CaSO4 : $0.409 \%$; MgSO4: $0.04 \%$; H2O : $0.63 \%$; Impurities: $0.65 \%$. Untuk mendapatkan garam KW 1 seperti yang ditargetkan tersebut, KKP akan memberikan sarana/media pembuatan garam berupa isolator kepada masyarakat yang menjadi anggota KUB Garam. Pelaksanaan PUGAR di Patipadatahun 2014, hampir samadengan pelaksanaan PUGAR tahun 2013 yaitu adanya keterlambatan memberikan media HDPL/Geomembranatau media LDPL/ isolator. Harapan pegaram, media tersebut dapat diterima pada bulan Mei/Juni tahun 2014, namun faktanya isolator dibagikan pada bulan September 2014, sehingga pegaram enggan untuk mengambilnya. Karena masyarakat pegaram belum dapatmenerapkan TTG TUF dengan media isolator. Hal ini disebabkan belum adanya bintek pemasangan isolator, keterbatasan faktor ekonomi pemadak dan belum adanya kepastian harga jual garam produk TUF. Kondisi tersebut merupakan permasalahan yang ada di lapang dan harus dicari solusinya.Pada saat masyarakat pegaram Pati kebingungan dalam pembuatan garam dengan sistem TUF pada media isolator, KIMBis melakukan uji coba pembuatan garam sistem TUF dengan menggunakan media yang berbeda yaitu media plastik terpal, Geomembran dan Isolator. Hasil uji coba menunjukkan bahwa media yang sesuai untuk pembuatan garam dengan sistem TUF adalah media isolator, dan garam yang dihasilkan 
secara visual berwarna putih bersih, butiran garam berupa kristal dengan ukuran diameter $\geq 4 \mathrm{~mm}$ dan hasil uji laboratorium menunjukkan kadar $\mathrm{NaCl} 94,2 \%$ dengan kandungan air $8,1 \%$ (BBIA, 2014). Garam hasil TUF pada media isolator dihargai oleh pedagang lokal Rp 600/kg di tambak. Untuk meyakinkan pegaram agar mau menggunakan media isolator dalam pembuatan garam, KIMBis melakukan sosialisasi langsung kepada para pembuat garam/pemadak tentang penggunaan media isolator dalam pembuatan garam dan memberikan jaminan harga garam lebih mahal Rp 100 per kg-nya dari pada garam tradisional. Setelah terbukti bahwa pembuatan garam sistem TUF dengan menggunakan media isolator memiliki beberapa kelebihan yaitu hemat waktu pengolahan lahan, efektif dalam pemanenan garam, memperpendek siklus pembuatan garam dan meningkatkan produksi garam. Setelah mengetahui nilai positip dari penggunaan media isolator dalam pembuatan garam, para pemadak telah bertekat bahwa pada musim garam tahun 2015 akan membuat garam dengan menerapkan TTG sistem TUF dengan media isolator, sehingga produksi dan kualitas garam dapat meningkat sesuai target yaitu garam KW 1 dengan produktifitas lahan per Ha mencapai 120 ton/musim (selama 4 bulan)

Pelaksanaan PUGAR di Kabupaten Pati pada tahun 2015 hampir sama dengan kejadian pelaksanaan PUGAR tahun 2014, yaitu Keterlambatan kedatangan bantuan media isolator hingga bulan Juli tahun 2015 belum tiba di Pati. Pada sisi lain, musim garam tahun 2015 lebih awal dari biasanya karena pengaruh elnino yang memberikan dampak jatuhnya musim kemarau lebih awal dari biasanya yaitu bulan Mei tahun 2015, sehingga masyarakat petambak garam wilayah Pati sebagian besar telah mulai mempersiapkan tambak untuk usaha pegaraman dengan menerapakan teknologi tradisional, dan ukuran petak mejaan garam yang dibuat berkisar $10 \times 30 \mathrm{~m}$.

Permasalahan kedua adalah perbedaan ukuran mejaan garam dangan ukuran lebar isolator, sehingga masyarakat kebingungan bagaimana cara mengatasinya. Untuk menyambung isolator dan teknis pemasangannya di petak mejaan. Melihat situasi dan kondisi tersebut, KIMBis melakukan perannya sebagi inkubator bisnis, dalam hal ini KIMBis secara swadaya membeli peralatan penyambung media isolator, kemudian KIMBis membuka usaha penyediaan jasa penyambungan media isolator dengan tarif $\mathrm{Rp} 3.500$ per meter lari. Selain itu KIMBis juga mengadakan pelatihan, bimbingan dan pengawalan secara langsung kepada masyarakat pegaram tentang teknis pemasangan isolator di mejaan. Dengan tersosialisasinya pembuatan garam dengan sistem TUF pada mejaan yang dilapisi isolator, maka garam yang dihasilkan minimal berkualitas KW 2. Bahkan seorang pengurus KIMBis yang menerapkan SOP pembuatan garam dengan media isolator secara benar, tertib dan disiplin, pada lahan seluas $1 \mathrm{Ha}$ dengan jumlah petak mejaan sebanyak sembilan petak, masingmasing berukuran $8 \times 20 \mathrm{~m}$, masa kristalisasi garam sembilan hari per panen, maka dalam 1 mejaan selama satu bulan telah menghasilkan garam super sebanyak $5.250 \mathrm{~kg}$. Sehingga dapat diprediksi bila musim kemarau dapat berjalan sampai bulan Oktober/November 2015 (tiga bulan untuk pembuatan garam pada tahun 2015), maka total produksi garam super yang dihasilkan dengan sistem TUF pada media isolator akan mencapai $141.750 \mathrm{~kg}$. Bila hal ini dapat terwujud, maka tujuan/sasaran Program PUGAR baru tercapai sebagian yaitu dapat meningkatkan produktifitas dan kualitas garam sedangkan untuk menjaga kestabilan harga garam belum dapat diwujudkan.

Dengan keberhasilan meningkatkan produksi dan kualitas garam, permasalahan lain mulai muncul yaitu harga garam produk isolator yang murah, karenapedagang garam lokal memberikan harga Rp 100 lebih mahal dari pada garam tradisional. Sebagai gambaran, pada saat ini (bulan Agustus Tahun 2015) harga garam tradisional super senillai Rp 325/kg, sedangkan harga garam isolator KW 2 senilai Rp 425/kg dan garam isolator KW1 dihargai $\mathrm{Rp} 525 / \mathrm{kg}$. Kondisi ini telahmempengaruhi semangat para pegaram dalam menerapkan TUF dengan media isolator, yang pada awalnya bersemangat tinggi namun saat ini semangatnya jadi turun. Untuk mengatasi masalah ini, pemerintah pusat yang terkait dengan komoditas garam (KKP, Perindustrian, Perdagangan dan Koperasi) turun ke lapang secara bersamaan untuk membuat kesepakatan bersama bagaimana cara mengatasi permasalahan harga garam setelah petambak garam sudah berhasil meningkatkan kualitas dan produksi garam sesuai dengan ketentuan pemerintah yaitu harga garam KW 1 sebesar 
Rp 750/kg dan garam KW 2 senilai Rp550/kg (Dirjen Perdagangan Luar Negeri, 2011).

\section{Pola Pembuatan Garam Tradisional}

Pola usaha pembuatan garam di Pati dilakukan pada musim kemarau yangpada umumnya terjadi pada bulan Juni hingga bulan November dan proses pembuatannnya dilakukan di tambak yang sebelumnya digunakan untuk pemeliharaan ikan bandeng atau udang. Tahapan proses pembuatan garam meliputi persiapan lahan, proses produksi dan panen. Persiapan lahan untuk wilayah timur (Kecamatan Batangan dan Yuwana) biasanya dilakukan lebih awal (bulan Mei) dari pada wilayah barat (Kecamatan Wedarijaksa dan Trangkil) yang dimulai pada bulan Juni. Pekerjaan persiapan lahan meliputi;

1. Pembuatan/pembagian petakan dalam tambak yang terdiri dari petak tandon $(\leq 40 \%)$, petak pinihan/jarangan (30\%), petak mejaan garam/koen $(30 \%)$, dan penataan pematang/galengan dan saluran sekunder.

2. Pengolahan tanah dan pemadatan mejaan garam, yang pekerjaannya meliputi (Pencangkulan membalik lapisan top soil tanah, membersihkan kotoran dari sisa budidaya dan meratakan tanah petakan, penjemuran tambak kurang lebih selama 20 hari, pengisian laut setinggi $5 \mathrm{~cm}$ dan dibiarkan sampai airnya habis dan permukaan lahan kering, pemadatan tahap 1 sampai permukaan tanah halus, pengeringan/penjemuran tahap II, pengisian air laut tahap 2 dan didiamkan sampai kadar air mencapai 10-16 Be, penjemuran tahap 3 selama 3-4 hari hingga kadar air mencapai 16 - 20 Be, kemudian air dibuang, Penjemuran tambak tahap 4 selama 1- 2 hari, pemadatan ke-3 (terakhir) sampai permukaan mejaan garam keras dan pembuatan garam siap dilaksanakan.

Proses pembuatan garam, Mula-mula mengalirkan air laut ke petak tandon/ penampungan kemudian disalurkan ke petak pinihan/jarangan secara bertahap hingga kadar air dari 4 Be menjadi $16 \mathrm{Be}$, kemudian air disalurkan ke dalam mejaan garam hingga ketinggian air mencapai $5 \mathrm{~cm}$ di atas permukaan mejaan garam dan didiamkan untuk proses kristalisasi.Proses kristalisasi garam, yaitu penguapan air di mejaan garam merupakan waktu yang dibutuhkan dalam pembuatan garam dan sangat berpengaruh terhadap kualitas garam. Pada hari ketiga di mejaan garam mulai tumbuh bunga-bunga garam dan pengkristalan, pada hari ketujuh permukaan mejaan garam telah penuh dengan garam dan siap untuk dipanen. Panen/penggarukan garam pada tahap pertama dilakukan setelah garam di mejaan minimal berumur tujuh hari sejak air tua dimasukkan ke dalam mejaan garam. Setelah panen garam, permukaan mejaan garam dirapikan lagi supaya rata dan padat dengan membutuhkan waktu

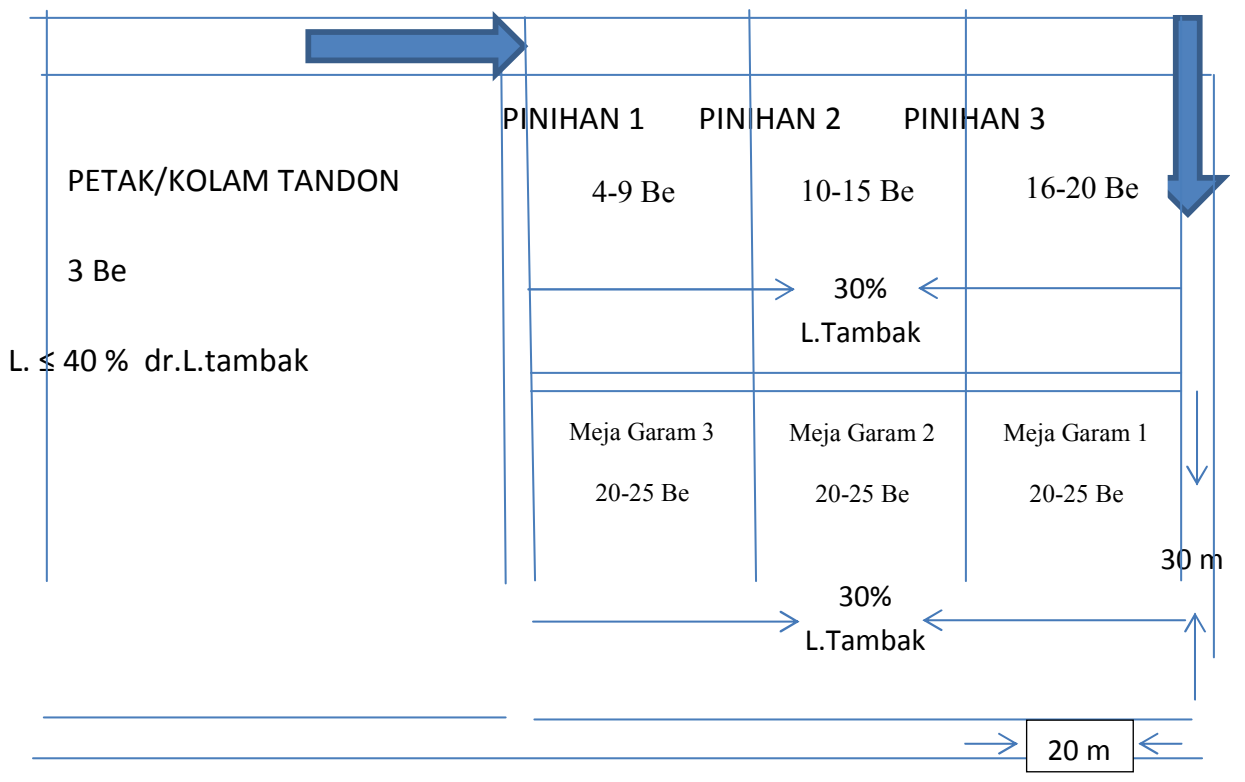

Gambar 1. Tahapan Proses Pembuatan Garam Tradisionalal di Kabupaten Pati. 
selama tiga hari, kemudian air tua dimasukkan lagi ke mejaan yang sudah siap. Penentuan panen garam untuk tahap ke-dua dan tahap seterusnya lebih banyak dipengaruhi oleh situasi dan kondisi perekonomian pembuat garam dan pasar garam. Kondisi perekonomian masyarakat pembuat garam di Pati pada umumnya termasuk dalam golongan ekonomi lemah, sehingga jarak panen garam antara tahap satu dengan panen tahap berikutnya hanya berselang $3-4$ hari garam di mejaan. Hal yang sama juga akan dilakukan oleh pegaram lainnya yang termasuk ekonomi kuat, bila permintaan garam cukup tinggi sehingga pegaram ingin cepat panen dan mendapat uang walaupun garam yang dijual nilainya rendah. Garam krosok yang dihasilkan dikategorikan dalam KW 3 (paling tinggi), yang secara visual ditunjukkan dengan garam berwarna putih kusam, butiran garam berupa kristal yang berukuran kurang dari $3 \mathrm{~mm}$. Kondisi demikian ini sering terjadi di Pati sehingga memberikan kesan bahwa garam Pati kualitasnya lebih rendah dari pada garam Madura.

\section{Pembuatan Garam Sistim TUF dengan Media Isolator}

Teknologi pembuatan garam dengan sistem TUF pada media isolator merupakan teknologi baru bagi masyarakat pegaram diPati. Teknologi ini baru diperkenalkan oleh PUGAR kepada masyarakat pegaram (khususnya di Pati) pada tahun 2013 menjelang musim kemarau berakhir, sehingga teknologi tersebut belum dapat diterapkan oleh pegaram. Namun demikian, KIMBis Pati telah berhasil mencoba menerapkan TTG pembuatan garam dengan sistem TUF dengan media terpal. Seiring dengan tujuan dan sasaran Program PUGAR, maka masyarakat pegaram Pati sudah mulai memahami dan mencoba menerapkannya hingga tahun 2015. Pembuatan garam Sistem TUF dengan media isolator pada prinsipnya sama dengan pembuatan garam tradisional, namun ada beberapa perbedan pokok yang dapat berpengaruh tehadap produksi dan kualitas garam yang dihasilkan. Perbedaantersebut meliputi :Pertama,adanya petak ulir yang diletakkan diantara petak tandon dan petak pinihan/jarangan.Petak ulir berfungsi untuk menyaring kotoran dan mengendapkan unsur unsusr-unsur kimia yang ada dlam air laut seperti kalsium, magnesium dan sulfat. serta meningkatkan kadar air dari 3 Be menjadi 8 $\mathrm{Be}-10 \mathrm{Be}$ melalui proses penguapan dengan cara memutar-mutar air melalui saluran yang dibuat seperti ulir. Filtertersebut terdiri dari abu gosok/silika, ijuk, arang batok, dan batu kerikil yang dimasukkan dalam kantong kain kasa. Penggunaan filter ini bertujuan untuk menyaring air yang masuk dan keluar dari setiap petakan menjadi bersih sehingga garam yang dihasilkan derwarna putih bersih. Perbedaan kedua adalah pemasangan media isolator pada mejaan garam dengan maksud untuk melapisi permukaan mejaan supaya dalam proses kristalisasi di mejaan tidak bersentuhan langsung dengan tanah, sehingga mempercepat proses kristalisasi dan mempercepat proses pembuatan garam untuk tahap kedua dan berikutnya serta mempersingkat dan mempermudah pekerjaan panen garam.

Setelah kadar kekentalan air di dalam petak ulir mencapai $8 \mathrm{Be}$, air dimasukkan ke dalam petak pinihan/jarangan untuk diproses lebih lanjut (peningkatan kekentalan) hingga mencapai $16 \mathrm{Be}-20 \mathrm{Be}$, kemudian air dimasukkan ke dalam petak mejaan garam setinggi $5 \mathrm{~cm}$ di atas permukaan mejaan garam untuk proses kristalisasi. Setelah terjadi kristalisasi di mejaan garam, dilakukan penambahan air laut $(20 \mathrm{Be})$ dari petak pinihan di atas garam yang sudah mengkristal setinggi $3-5 \mathrm{~cm}$, begitu seterusnya dilakukan penambahan air pinihan setiap 2 hari sekali sampai ketinggian air mencapai $5 \mathrm{~cm}$ lagi dan penambahan air ini dilakukan sampai garam berumur minimal 7 hari. Penambahan air pinihan ke atas kristal garam dimaksudkan untuk meningkatkan kristal garam dan meningkatkan kepadatan volume garam. Setelah kristal di mejaan garam minimal berumur 7 hari dilakukan pemanenan pertama dengan cara digaruk seperti panen garam tradisional. Panen berikutnya di petak mejaanyang sama dilakukan minimal 7 hari atau sesuai dengan jumlah petak mejaan garam yang ada, sehingga panen garam dapat dilakukan setiap hari. Kelebihan penggunaan isolator lainnya adalah tidak adanya perbaikan permukaan mejaan garam setelah panen, sehingga pembuatan garam berikutnya dapat dilakukan secara langsung tanpa meratakan permukaan mejaan garam. Kondisi inilah yang menyebabkan hasil panen garam TUF dengan media isolator lebih banyak dari cara tradisional. 
Tabel 1. Perbandingan Pembuatan Garam Tradisional dengan Garam Sistem TUF dengan Media Isolator.

\begin{tabular}{|c|c|c|}
\hline KETERANGAN & CARA TRADISIONAL & SISTEM TUF DENGAN MEDIA ISOLATOR \\
\hline Pembagaian petakan tambak & $\begin{array}{l}3 \text { petakan (tandon, } \\
\text { pinihan, mejaan) }\end{array}$ & 4 petakan (tandon, ulir pinihan, mejaan) \\
\hline $\begin{array}{l}\text { Perbandingan luas petakan terhadap } \\
\text { luas total }\end{array}$ & $\begin{array}{l}\text { Ptk Tandon }(40 \%) \text {, Ptk } \\
\text { Pinihan }(30 \%) \text {, Ptk Meja } \\
\text { Garam }(30 \%)\end{array}$ & $\begin{array}{l}\text { Ptk Tandon (50\%), Ptk Ulir (20\%), Ptk } \\
\text { Pinihan (15\%), Ptk Meja Garam (15\%) }\end{array}$ \\
\hline Ukuran meja garam & $10 \times 30 \mathrm{~m}$ & $8 \times 21 \mathrm{~m}$ \\
\hline $\begin{array}{l}\text { Alur dan kadar air laut dalam proses } \\
\text { pembuatan garam }\end{array}$ & $\begin{array}{l}\text { Tandon }(3 \mathrm{Be})-\text { Pinihan } \\
(4-20 \mathrm{Be})-\text { Meja garam } \\
(21-25 \mathrm{Be})\end{array}$ & $\begin{array}{l}\text { Tandon }(3 \mathrm{Be})-\text { Ulir }(4-8 \mathrm{Be})-\text { Pinihan }(9 \\
-20 \mathrm{Be})- \text { Meja garam. }(21-25 \mathrm{Be})\end{array}$ \\
\hline $\begin{array}{l}\text { Kadar kekentalan Air masuk } \\
\text { kristalisasi }\end{array}$ & $20 \mathrm{Be}$ & $20 \mathrm{Be}$ \\
\hline Ketinggian air kristalisasi & $2,5-3 \mathrm{~cm}$ & $5 \mathrm{~cm}$, tambah air per 2 hari \\
\hline Waktu kristalisasi /panen & 3 hari & 7 - 9 hari \\
\hline Produksi / petak meja garam & $700 \mathrm{~kg}$ & $1.750 \mathrm{~kg}$ \\
\hline Frekwensi panen/bulan & 5 kali & Maksimu 4 kali \\
\hline Kwalitas garam & KW 3 & KW 1 (Super) \\
\hline Harga/ kg & Rp 300 & $\operatorname{Rp} 500$ \\
\hline $\begin{array}{l}\text { Produksi/petak meja garam per } \\
\text { bulan }\end{array}$ & $3.500 \mathrm{~kg}$ & $5.250 \mathrm{~kg}$ \\
\hline
\end{tabular}

Sumber : Data primer, Bulan Agustus 2015

\section{Analisa Usaha}

Hasil perhitungan analisa usaha (terlampiran) pada dua cara pembuatan garan (tradisional dan sistem TUF dengan media isolator) pada luasan yang sama (1 Ha) menunjukkan bahwa;

a. Produksi garam dengan cara sistem TUF pada media isolator dapat meningkatkan produksi $69 \%$ dari produksi garam tradisional 84.000 ton/Ha menjadi 141.750 ton/Ha per musim

b. Kualitas garam meningkat dari KW 3 (tradisional) menjadi garam $\mathrm{KW} 1$, sehingga harga garam lebih mahal,

c. Keuntungan yang diperoleh lebih besar dan secara ekonomi usaha pembuatan garam dengan sistem TUF pada media isolator layak dilanjutkan, karena $\mathrm{R} / \mathrm{C}$ Rationya 1,206 dan Imbangan penerimaan biaya $=20,56 \%$. Kondisi ini mengindikasikan bahwa usaha pegaraman sistem TUF dengan media isolator masih layak untuk dibiayai dari pinjaman Bank dengan bunga $25 \%$ per tahun.

d. Pekerjaan dalam proses pembuatan garam lebih ringan dan tidak ada jeda waktu untuk perbaikan meratakan mejaan garam, sehingga dapat dilakukan panen garam setiap hari.

e. Usaha pembuatan garam cara tradisonal memberikan keuntungan, tetapi secara ekonomi tidak layak untuk dilanjutkan. Karena keuntungan yang diperoleh sanagat kecil (imbangan penerimaan biaya $=1,43 \%$ ), sehingga tidak cukup untuk mengangsur ke Bank. Seandainya modal usaha dapat pinjaman dari Bank dengan bunga $12 \%$ per tahun.

\section{KESIMPULAN DAN IMPLIKASI KEBIJAKAN}

\section{Kesimpulan}

1. Keberhasilan pelaksanaan Program PUGAR perlu dilakukan sosialisasi, Bimtek dan, pembuatan demplot serta pendampingan dan pengawalan secara langsung kepada masyarakat yang menerapkannya.

2. Program PUGAR dapat meningkatkan produktifitas dan kualitas garam menjadi KW1, apabila diterapkan sesuai dengan SOP.

3. Ketepatan waktu dalam menyerahkan bantuan kepada masyarakat akan memberikan manfaat maksimal, 


\section{Implikasi Kebijakan}

1. Pemerintah pusat yang terkait dengan komoditas garam (KKP, Perindustrian, Perdagangan dan Koperasi) diharapkan dapat menjaga stabilitas harga garam yang telah ditentukan dengan cara membuat kebijakan tentang pemasaran garam mulai dari daerah produsen hingga pabrik pengolahan /industri yang membutuhkan garam.

2. Koperasi garam yang telah dibentuk, perlu diperdayakan dalam pelaksanaan Program PUGAR, dengan cara melakukan kerja sama dengan KIMBis Bumi Sarmina Pati. mulai dari pelaksanan penerapan teknologi proses pembuatan garam hingga pemasarannya.

3. Pemerintah Daerah (Pemda) memberikan dukungan penuh terhadap pelaksanaan Program PUGAR, melalui penyediaan gudang garam dan mengeluarkan regulasi pegaraman tingkat daerah.

\section{DAFTAR PUSTAKA}

Agung, I. G. N. 2011. Manajemen Penulisan Skripsi, Tesis dan Disertasi. Rajawali. Jakarta

BBIA. 2014. Hasil uji garam produksi TUF dengan media isolator, Laboratorium Analisis dan Kalibrasi, Balai Besar Industri Agro Bogor

BMKG. 2012. Peran Unsur Iklim dan Cuaca Dalam Pemberdayaan Usaha Garam Rakyat (PUGAR). Badan Metorologi, Klimatologi dan Geofisika (Unpublished).

BALITBANGKP. 2012. SK Ka. Badan Litbang KP no.12.1/BALITBANGKP/RS.210///2012, tentang Pembentukan Klinik Iptek Mina Bisnis (KIMBis).

BBPSEKP. 2012. Laporan Akhir Tahun Kajian Pengembangan Kawasan Minapolitan Produk Kelautan Dalam Mendukung Industrialisasi. (Unpublished).

Hariyanto. 2013. Paparan Bupati Pati "Permasalahan Dan Solusi Pengembangan Bahan Baku Dan Garam Beryodium Di Kabupaten Pati" disampaikan pada acara Sosialisasi Paten Proses Pembuatan Garam NaCl Dengan Media Isolator Pada Meja Kristalisasi
(Nomor Paten Id P0033348), Kementerian Perindustrian, Semarang 16 Mei 2013.

Dinas Kelautan dan Perikana Kabupaten Pati. 2012. Laporan Tahunan Dinas Kelautan dan Perikanan Kabupaten Pati. Kabupaten Pati.

Dinas Kelautan dan Perikana Kabupaten Pati. 2013. Laporan Tahunan Dinas Kelautan dan Perikanan KabupatenPati. Kabupaten Pati.

Direktur PMPPU. 2012. Menuju Swasembada Garam Nasional. Direktur Pemberdayaan Masyarakat Pesisir dan Pengembangan usaha.

Ditjen Perdagangan Luar Negeri, 2011. SK Peraturan Direktur Jenderal Perdagangan Luar Negeri No. 02/DAGLU/PER/5/2011, tentang harga dasar garam yang harus dibeli oleh Importir Produsen (IP).

Ditjen KP3K, 2013.Petunjuk Teknis Pelaksanaan Program PUGAR Tahun 2013 (unpublish) Ditjen KP3K. 2011.

Ditjen KP3K. 2012. Data Pemberdayaan Usaha Garam Rakyat (PUGAR). Kementerian Kelautan dan Perikanan. (Unpublished).

Ditjen KP3K, 2012. Pelaksanaan Pugar 2012. Direktorat Jenderal Kelautan, Pesisir dan Pulau-pulau Kecil.

Erlina, M. D, 2013. LAPORAN TEKNIS Kajian Aspek Sosial Ekonomi Pengembangan Garam Industri dan Produk Garam Derivatif (unpublis).

Kurniawan, T., Azizi, A. dan Yanti, B. V. I. 2011. Analisis Pendapatan Usaha Pegaraman di Kabupaten Pati. Prosiding Seminar Nasional Nasional Riset dan Kebijakan Sosial Ekonomi Kelautan dan Perikanan Tahun 2011.

Pedoman Pelaksanaan PNPM Mandiri KP dan Pedoman Teknis Pemberdayaan Usaha Garam Rakyat (PUGAR) Tahun 2011.

Sanusi. 2012. Proses Pembuatan Garam dengan Teknologi Ulir Filter (TUP). Petambak Garam Flowen Aras, Ambulu Losari, Cirebon. (Unpublished). 
Sutoyo, S. 2002. Studi Kelayakan Proyek. Konsep, Teknik \& Kasus. Cetakan 2, PT Damar Mulia Pustaka. Jakarta.

Zulham, A. 2012. Pedoman Pelaksanaan Kegiatan Pengembangan Klinik IPTEK Minabisnis. BBPSEKP, Balitbang KP, Jakarta. (Unpublished). 